\title{
Best Practice
}

Jackie Fowler

is director of publications of social marketing agency Burnett Associates. During nearly ten years at the agency she was client services director before setting up Burnett

Publications three years ago. She has directed a wide range of charity campaigns, from direct marketing programmes to corporate identity, for non-profit clients large and small. She has been account director in the partnership with Botton Village for most of her time at Burnett Associates.

Keywords: Accountable, individuals, listening, personal, responsible, relationships
Jackie Fowler,

Burnett Associates,

White Lion,

74 Rivington Street,

London EC2A $3 \mathrm{AY}$

Tel: +44 (0)20 74153333

E-mail:

jackief@burnettassociates.com

\section{Botton Village's fundraising success}

Jackie Fowler

Received (in revised form): 11 January 2000

\begin{abstract}
Botton Village is a small charity which has achieved outstanding results through database-driven direct marketing. Firmly committed to the principles of 'relationship fundraising' - building funds by developing long-lasting, mutually beneficial relationships with its donors - it has shown that listening and responding to your customers' needs can really work. As a small player in one of the largest direct-mail-using sectors, it is a remarkable story.
\end{abstract}

\section{Introduction}

Botton Village is a remarkable success story: a small charity, based in the heart of the North York Moors, which has a fundraising track record that is the envy of many charities ten times its size. Despite having small budgets and no professional fundraising staff, it has used database marketing to create a gross income of around $£ 3.4 \mathrm{~m}$ per year.

\section{A bit of background}

Botton Village is a working community for adults with special needs (a range of mental handicaps). It is situated in Danby Dale in the North York Moors National Park. Part of the Camphill Village Trust, Botton has ten workshops and five farms. People with special needs - over half the community - live and work alongside 'co-workers' in extended families; everyone enjoys a full working, social, cultural and family life. Each contributes to the community to the best of their ability but no member of the community receives a wage. People with special needs are able to thrive, often for the first time in their lives.

\section{Where did it all start?}

Although the village was set up by a small, pioneering group of people 45 years ago, it was only around 16 years ago that the village found itself in the position of needing to raise new funds to supplement grants and the income from its own produce in order to grow.

In partnership with Burnett Associates, Botton Village put out tentative feelers into the world of fundraising through direct marketing. As a result the village has been transformed. New family homes give more people the chance to live at Botton; better workshops and farm buildings, equipment, and a community centre have improved opportunities enormously. And it now has tens of thousands of loyal friends and ambassadors throughout the country and overseas. 
Fowler

One of the most competitive sectors

\section{A history of innovation}

\section{Fundraising in a tough market}

No one should imagine that British fundraising is unsophisticated. The task of asking people for money — particularly by direct marketing - gets harder as competitive activity mounts. Fundraising is now the second biggest sector in direct mail - only financial services make greater use of the medium.

\section{A customer-driven relationship}

The current convention for British direct mail fundraising is to recruit new donors via cold direct response media and reciprocal mailings (list swaps with other charities), to send them a regular programme of mailed appeals and to 'upgrade' them to higher or more regular donations or direct commitment. The final prize is a legacy.

It is often a high-investment formula. Many acquisition programmes run at a net loss, although charities increasingly look for a return on investment in terms of lifetime donor value. From the donor's point of view it can be a tiresome process: give once and you will be asked again and again. Donors are increasingly sceptical about being 'marketed to' by charities, about being asked too often, not listened to, and mailed through list swaps by more and more charities they have never supported before.

Against this background, the relationship between Botton Village and its donors has always been unconventional - and even controversial, in the eyes of many other charity fundraisers. Donors are encouraged to choose the nature of that relationship. What, when and how much they hear about the charity is their choice, not the charity's. (So often, charities pay lip service to such principles but will not follow them through if it leads to a short-term loss of income - no matter what the effect on the longer-term relationship.)

The staggering success of the programme demonstrates the efficacy of a relationship owned and directed by the customer. For there are now 73,000 of them.

\section{Sound strategy}

This principle of relationship fundraising has always been at the heart of the village's fundraising strategy. Allied to this strong belief has been the need to make limited budgets work hard. Together these principles have led the village to take risks, to test extensively, to innovate and to harness the best of database technology to turn their principles into an efficient and effective direct-marketing-driven fundraising programme.

\section{Building the database: Where do you find new donors?}

When the village first dipped a toe in the water, at a time when charity direct marketing was far less sophisticated that it is today, it had everything to learn.

What sort of story should it tell? Should it feature male or female villagers, and of what age? What media should it try - and what sort of prospects should it target? What formats would work? And what kind and level of gift should it be asking for? And what then...? 


\section{Continuing to learn}

\section{Telling a \\ positive story}

\section{Testing 'the ask' \\ - levels and types of giving}

Over the years it has tested all these things and far more (from outer envelope messages to reply-form formats to many different creative formats and messages), slowly and gradually learning.

The original learning was achieved through direct mail. As different creative packs were tested and the database grew, more accurate profiling information and in-depth learning through qualititative and quantitative research became available, based on people who had already chosen to give.

At times in the past, household delivery based on postcode targeting and press inserts in publications whose circulation lists most closely matched current donor profiles have worked well. But each has turned out to be just for a time.

Direct mail, both cold and reciprocal, has held up robustly: Botton continues to test refinements and fresh creative approaches and response options against its banker pack, and to try to find and test new sources of names.

The creative story is an interesting one. So many charities elicit that first gift through images which draw pity and even induce guilt. Negative images of people suffering are par for the course. But Botton quickly found that its gut instinct about what was right for its own particular set of principles and beliefs paid off: its banker packs for years have shown individuals living rich and fulfilled lives. People respond with warmth and enthusiasm to the chance to support people making a success of their lives in a place that is tangible and real.

It has tended to be stories based around an older woman villager which have worked best. Sadly, experience has shown that key people featured in cold packs do need to be visually attractive and have visually obvious special needs. It seems potential donors are not yet ready to accept a more complex message. But principles aside, obviously Botton accepts this. It merely means that once someone has given, quite apart from encouraging a second gift, the programme needs to lead the new donor on carefully so that they find out more about the village, its philosophy and the wide range of people who benefit from living there.

Today's banker pack features Lesley. A short letter from her housefather introduces Lesley and her life in the family and in the village. A series of three photographs show Lesley in her daily life at work, with a friend, and with her Botton family: through handwritten captions on the back of each photo, Lesley talks proudly about her life and her achievements in the village.

For some years the banker pack has suggested a particular level of one-off gift ( $£ 19$, which is suggested and explained throughout the pack). Recently, low-level committed giving has been tested (asking for a small, regular monthly gift); while the return on investment at point of recruitment may be lower, this may well pay off in a better return on investment in the long term, since donors recruited that way are much less likely to lapse.

Today, the cold mailing programme recruits donors at an average cost of around $£ 17$ at the point of recruitment; however, new donors pay for themselves within just six months through additional gifts to the village. 
It's the second gift that really counts in a longer-term relationship

\section{The importance of saying thank you quickly}

\section{Tracking response patterns}

Reciprocal mailings do even better. During the last complete year, Botton added a total of 6,400 new donors at a net profit per new donor of £5.79. Response rates were as high as 7.8 per cent — sometimes higher than the 'owner' charity's own warm response rates from these people.

\section{Turning one-off responders into friends: The welcome cycle}

All charities know that the first gift is just the beginning. There can be many reasons why donors may choose never to give again, so the task of motivating a second gift can be a tough challenge. In the case of Botton, most first-time donors have never come across this small community before.

Over the years Botton has tried and tested different ways of welcoming people into the community as friends. And the need to track if, how and when donors 'convert' to a second gift is just one of many reasons why Botton has found that using the most up-to-date database technology is absolutely critical.

\section{Welcoming new friends}

Botton thanks new donors promptly - usually within 48 hours. Most people giving for the first time really appreciate a response that comes quickly, while the gift is still fresh in their minds - and experience shows that it affects future giving too. The village welcomes the new donor warmly, sends some brief information introducing Botton, and explains what will happen next.

Donors move into the programme of warm mailings - usually four a year, based around the community's newsletter, Botton Village Life $(B V L)$ - but within a 'welcome cycle'. A friendly letter with their first newsletter acknowledges them as newcomers, and welcomes them to the newsletter explaining what they will find in it. They move successively through four donor mailings, each with an appropriate letter, and if they have not responded they are then reminded at around the time of the anniversary of their first gift. At every stage of this process they are offered choices about how often they would like to hear and what they would like to receive from Botton - and they are even offered the choice not to hear from Botton at all again.

If they do not give a second gift, several reminder stages explain that if Botton does not hear from them soon indicating what sort of relationship they would like, they will in future hear from the village just once a year at Christmas, in order not to waste the value of their first gift. (They would then be mailed just once a year for several years, before being 'lapsed' - again with notice.)

Throughout this welcome process each segment is carefully monitored - so that Botton can track how many 'convert' to a second gift at each stage, giving patterns, and how findings can feed into improvements in the programme. Most recently, a simple mid-cycle mailing is being tried at around a year after the first gift; and additional steps will soon be tested to lead the donor through from their first gift to the regular $B V L$ mailings. 
Donors are always welcome

The newsletter is an ideal way to bring the village to life

\section{A personal approach}

Botton finds that on average around 50 per cent of first-time donors give again. Many do so within three months of their first gift (typically 15-19 per cent); response rates gradually decline over the first year, and through the reminder period. But Christmas always acts as a boost to the figures throughout every segment, making it good sense after a time to cut down on the costs of regular mailings but to remain in contact at a time when response rates tend to be far higher.

\section{Treating donors as real people}

Botton has always respected its donors, and believes that its success depends on nurturing them as friends.

From the annual open day, to making visitors welcome, to encouraging dialogue and comments, Botton has always gone out of its way to be open, friendly and warm - to make donors feel they are dealing with real people.

There are many measures of how people respond to this - whether it is families building their summer holiday around a visit to Botton, the sackloads of personal Christmas cards received in the village each year or individuals choosing to fund particular much-needed items in new houses or workshops.

\section{The donor development programme - Keeping Botton's friends in touch}

The main vehicle of communication is again Botton Village Life. The format of a newsletter gives the opportunity to bring the village to life through stories of everyday life in the village - from interviews with new villagers, to insights into life in the family houses, to following Botton's duck-keeper, store-keeper, or one of its farmers for the day. Through it you see people with special needs living their lives with pride and humour; you get to know the characters, the houses, the layout of the village's network of farms, workshops and houses.

The newsletter also gives feedback on projects made possible with donors' help, and introduces projects which will soon need funding, showing why, in people terms, they are necessary. It is also very flexible - just one creative approach can be tailored through a letter and reply form to everyone, keeping costs and administrative time to the minimum.

With the newsletter comes a very personal letter talking about what the village needs and why - usually from John Durham, a housefather at Botton as well as chairman of the fundraising group. Newsletter and letter are accompanied by a reply form (no particular gift amounts are suggested), and sometimes either a covenant form (for tax-effective giving) or an additional flyer explaining a current project in more detail. Those who have chosen to receive information only get neither a direct appeal nor a reply form.

With each mailing every donor gets a simple sheet offering them choices about their relationship (what they would like to receive, how often, when - or not at all), further information (a video, information about visiting, or to find out more about leaving a legacy), the chance to visit the village, encouraging them to call named people in the office 
Fowler

Acknowledging the donor's relationship
No paid

professional fundraising staff with queries or comments (a friendly group photo shows the faces behind the names). Entitled 'Let Botton help you', it turns the traditional charity-donor relationship on its head - this is about the village answering your needs, not just about what you as a supporter have to contribute.

\section{Using the database to tailor treatment}

Each mailing contains between 17 and $20+$ different segments. Letters are tailored and personalised to recognise donors' communication choices (for example Christmas only, just information but not appeals etc), their past giving (such as committed giving, frequent, recent or very generous support), the stage of the relationship they are at (newcomers, those who have not given for some time) and the type of supporter they are (individual, company, trust). Reply forms too are tailored where necessary.

Responses are monitored by segment - you can see clearly how frequency, value and type of gift vary from group to group; and learning is put to good use to develop the programme further. For example, covenant renewals have now been switched to a simple single-focus letter mailed mid-cycle.

\section{Panel - A word about the fundraising team}

Botton's fundraising team is unusual and tightly stretched by any charity's standards. There are no full-time, paid, professional fundraisers among them. The fundraising group consists today of four co-workers (each has another full-time job within the village, as well as being houseparent of a home made up of their own direct family and a group of villagers with special needs) and a small office which organises the adminstrative side of the programme. Also involved in this group are Lawrence Stroud (who was instrumental in setting up and managing the programme while he was a Botton housefather, but who has now moved out of the village; he continues to play an active role in its fundraising) and a small team from Burnett Associates.

\section{Results - The proof is in the pudding}

Botton's results from its warm mailings speak for themselves.

- Once a donor has given a second gift, they tend to stay for many years. Around 55 per cent have been donors for over four years, and 20 per cent for more than seven years.

- Botton Village now has around 73,000 supporters either in the welcome cycle, active or 'failing' (no recent gift but not yet classed as 'lapsed'). In 1998 donations and legacies totalled $£ 3.4 \mathrm{~m}$.

- Forty-one per cent of donors have chosen to hear from the village just once a year at Christmas (which means that for three out of four mailings per year Botton cuts costs and mails around 47,000 people).

- Actual response rates and average donation levels vary depending on the time of year, so typical response rates will be given. In March 1998, for example, active donors who had given within the last 12 
Response rates of $45 \%$ and over

\section{Bequests tend to be worth many times more than gifts during the donor's lifetime}

\section{Listening and responding personally}

months responded at 32 per cent; those who had given gifts of over $£ 250$ responded at 37 per cent, and 'multiples' — those who tend to give several times within a year - responded at 45 per cent. Even those with active covenants responded at 17 per cent (many Botton donors have more than one covenant active at any time). Those who had requested no appeals, just information, responded at 20 per cent and 31 per cent of those who had given a gift during the previous three months gave again. The response rate overall to this mailing was 20 per cent, with an average gift of $£ 50.85$.

- Move to Christmas 1998 and results are even higher. Those who had chosen to hear just at Christmas responded at 45 per cent - and even Christmas-only donors who already held an active covenant responded at 34 per cent (with an average gift of £102). Of those who had asked for 'information only' at Christmas, with no appeal and no reply form, 39 per cent gave a gift! The Christmas 1998 mailing to around 73,000 donors raised a total surplus, after all costs, of over $£ 760,000$.

- A simple covenant renewal mailing (an A4 letter and enclosed reply form) mailed mid-cycle achieved a response rate of 60 per cent within a few weeks.

\section{The role of legacies}

For most charities legacies are the ultimate gift. A donor who gives low-level gifts during their lifetime is able to make a bequest many times that size which still remains a small part of their overall estate. While many charities proactively ask donors to leave legacies, Botton prefers to show by example what such gifts have made possible, and to offer useful information to anyone interested in the subject.

Even this relatively low-profile approach has yielded spectacular results. Until several years ago legacy income was doubling year on year. Legacies have now levelled off and contribute around $£ 500,000$ of income each year.

\section{Significant milestones and learnings (just a few)}

\section{Taking criticism seriously}

Early on, Botton found that the most vociferous complainer could be turned into the most ardent friend and loyal ambassador, if listened to and answered properly. Despite the small number of staff, Botton takes time to answer all criticisms and questions fully.

\section{Apologising after mistakes}

It is always worth being honest about mistakes. When Botton mailed one segment by mistake, it wrote, explained how the mistake had happened, and apologised. The result? Letters of goodwill, and yet more donations.

\section{Tick boxes/prompt levels}

Charity donors get bombarded with mail. Increasingly, there is bad feeling about 'pressurising' pre-printed donation prompt levels and 


\section{A bold step: helping other Camphill communities}

'tick-box options' suggesting how much to give. After an increasing level of unsolicited feedback from donors disliking this marketing technique, Botton decided to follow its donors' wishes and no longer use them. The result? Average donations and response rates remained just as high as ever, and donors felt they had been listened to.

\section{The outlook for the future}

Botton Village is currently engaged in an expensive programme of overhauling and upgrading every family house in line with new legislation and modern equipment needs. However, once that is complete, it foresees a time when it will no longer need the current level of income it gains from fundraising.

Rather than run down the donor base by failing to recruit new supporters to replace attrition, it is attempting something much bolder and more visionary.

It is gradually introducing donors to 'Botton's wider family' - the other Camphill communities. Already, once a year, it trails the needs of another community, and then invites most donors (all except those in the welcome cycle and therefore not yet committed to Botton, Christmas-only donors, and those who have specifically asked to hear only about Botton) to give a one-off gift to help that other community.

The Botton/Camphill balance can be changed in future according to need - the key thing is that Botton recognises that the resource it has built up is invaluable, and that its database of friends can be just as powerful a tool in helping other struggling communities to develop.

\section{Note}

Please note that throughout this paper figures given are for the last calendar year for which complete results are available: January to December 1998. 